\title{
Thioautotrophic ectosymbiosis in Pseudovorticella sp., a peritrich ciliate species colonizing wood falls in marine mangrove
}

\author{
Adrien Grimonprez ${ }^{\mathrm{a}, *}$, Audrey Molza ${ }^{\mathrm{b}}$, Mélina C.Z. Laurent ${ }^{\mathrm{a}}$, \\ Jean-Louis Mansot ${ }^{\mathrm{b}, \mathrm{c}}$, Olivier Gros ${ }^{\mathrm{a}, \mathrm{c}}$ \\ ${ }^{a}$ Sorbonne Universités, UPMC Univ Paris 06, Univ Antilles Guyane, Univ Nice Sophia Antipolis, CNRS, Evolution Paris Seine-Institut de \\ Biologie Paris Seine (EPS_IBPS), 75005 Paris, France \\ ${ }^{\mathrm{b}}$ GTSI, département de physique, UFR des Sciences Exactes et Naturelles, BP 592, 97159 Pointe-à-Pitre Cedex, Guadeloupe, France \\ ${ }^{\mathrm{C}}$ C3MAG, UFR des Sciences Exactes et Naturelles, Université des Antilles, BP 592, 97159 Pointe-à-Pitre, Guadeloupe (French West Indies), \\ France
}

\begin{abstract}
Ciliates represent a diversified group of protists known to establish symbioses with prokaryotic micro-organisms. They are mainly phagotrophs and symbiotic relationships with bacteria can give them an important advantage in chemosynthetic environments. The aim of this study is to describe the thiotrophic association that occurs between the peritrich ciliate Pseudovorticella sp. and potential sulfur-oxidizing bacteria. Investigations at microscopic scale (LM, SEM, TEM) showed ectosymbiotic bacteria covering the surface of the body of Pseudovorticella sp. According to 16S rDNA phylogenetic analysis, these ectosymbiotic bacteria belong to $\gamma$-proteobacteria and are phylogenetically close to the symbiont of the recently described Zoothamnium ignavum, which inhabits shallow-water wood falls. FISH experiments, using symbiont specific probes, clearly indicate that these ectosymbiotic bacteria are also ingested into food vacuoles. Electron lucent granules observed in TEM in the cytoplasm of the ectosymbiotic bacteria have been identified as sulfur granules by Raman microspectrometry analyses. Raman microspectrometry analyses confirmed the thiotrophic nature of this relationship already suggested by the results obtained by TEM and phylogeny. A complete sulfur map was then performed to investigate the sulfur distribution in the zooid. Results show that the relationship between this protist and its bacterial partner is a thiotrophic ectosymbiosis.
\end{abstract}

Keywords: Protist; Raman; Sulfidic environment; Symbiosis; Ultrastructural analysis

Abbreviations: BLAST, basic local alignment search tool; FISH, fluorescent in situ hybridization; LM, light microscopy; MUSCLE, Multiple Sequence Comparison by Log-Expectation; PCR, polymerase chain reaction; rRNA, ribosomal ribonucleic acid;

SEM, scanning electron microscopy; TEM, transmission electron microscopy.

*Corresponding author.

E-mail addresses: Adrien.Grimonprez@etu.univ-antilles.fr (A. Grimonprez), audrey.molza@univ-antilles.fr (A. Molza), melina.laurent@developpement-durable.gouv.fr (M.C.Z. Laurent), jlmansot@univ-ag.fr (J.-L. Mansot), olivier.gros@univ-antilles.fr (O. Gros). 


\section{Introduction}

Ciliates represent an extraordinarily widespread group of protists (single celled eukaryotic organisms) occurring in almost all aquatic environments (Dziallas et al. 2012; Lynn 2008). These organisms are abundant phagotrophs (grazers of algae, bacteria, and other micro-organisms) in the biosphere and can form extensive blooms (Dziallas et al. 2012; Gast et al. 2009; Taylor and Sullivan 1984). Thus, they promote the re-mineralization of microbial biomass, thereby increasing the transfer of nutrients to other organisms (Dziallas et al. 2012). Ciliates can also harbor bacteria and/or algae in the frame of both endosymbiotic and ectosymbiotic relationships either in aerobic or anaerobic environments (Gast et al. 2009; Rosati 2004). All mutualistic symbioses between prokaryotes and eukaryotes are related to nutrition, protection and catabolism (Moya et al. 2008; Sauvadet 2015). Some protists, as Kentrophoros sp. or Zoothamnium niveum, cultivate and use their ectosymbionts as food sources (Ott et al. 2004). Ectosymbionts of Euplotidium sp. protect the ciliates ingestion by predators by changing the ciliate surface preventing its identification (Rosati et al. 1999). Whereas, Caedibacter bacterial endosymbionts of Paramecium promote the growth of their host by giving them the ability to kill Paramecium individuals lacking these bacteria (Kusch et al. 2002). Unlike the diversity of function held by prokaryotic symbionts, eukaryotic photosynthetic organisms are more common as symbionts in protists (Sauvadet 2015). This is particularly the case with the freshwater ciliate Paramecium bursaria that contains green algae of the genus Chlorella (Esteban et al. 2010).

Mangroves represent thiotrophic environments known to offer a variety of habitats for symbioses (Laurent et al. 2009; Ott et al. 2004) as well as hydrothermal vents, cold seeps and whale falls (Cavanaugh et al. 2013; Dubilier et al. 2008). However, the predominance of photoautotrophic organisms restricts these thiotrophic symbioses to a cryptic existence in highly localized zones (Ott et al. 2004). The process by which sulfides are produced in mangroves occurs both on and in the sediment, by the plant material degradation involving the microbial activities of cellulolytic bacteria and sulfate reducing bacteria (SRB) in anaerobic conditions (Bienhold et al. 2013; Fors et al. 2008; Palacios et al. 2009). Conversely to geothermal process (Dubilier et al. 2008), the debris derived from mangrove plants, algae, or sea grass may accumulate and the decomposition of this organic matter creates sulphidic habitats of various spatial and temporal extents (Ott et al. 2004). This sulfur production allows the development of free-living thiotrophic bacteria (Fenchel 1994; Jean et al. 2015; Jorgensen et al. 2013; Stocker and Seymour 2012) or bacterial symbionts that are associated with invertebrates and ciliates both in and on the sediment (Ott et al. 2004). In Guadeloupe's mangrove, endosymbiotic sulfur-oxidizing bacteria were previously described inside the gills of Phacoides pectinatus living in the sediment (Frenkiel et al. 1996). On the other hand, ectosymbiosis occurs between sulfur-oxidizing bacteria and ciliates (Laurent et al. 2009; Maurin et al. 2010), nematoda (Himmel et al. 2009; Maurin et al. 2010) and polypes of medusozoa (Abouna et al. 2015). To our knowledge, the only thiotrophic relationship involving ciliates described from mangrove wood falls ecosystem concerns the peritrich ciliate Zoothamnium niveum and sulfur oxidizing bacteria (BauerNebelsick et al. 1996b; Laurent et al. 2009; Maurin et al. 2010; Ott et al. 2004). However, naturally sunken wood (including leaves) might constitute substantial habitats for organisms relying on thiotrophic symbiosis (Bienhold et al. 2013; Fagervold et al. 2012; Laurent et al. 2009). The aim of this study was to characterize the symbiosis between a ciliate belonging to Vorticellidae, colonizing sunken leaves, and its potential new thioautotrophic symbionts in marine tropical mangrove environment from Guadeloupe. Phylogenetic analyses of 16S and 18S rRNA gene sequences allowed identifying both partners and revealed that these symbiotic bacteria are close to Candidatus Navis piranensis, a novel genus of bacteria living in symbiosis with the ciliate species Zoothamnium ignavum (Schuster and Bright 2016). The symbionts were detected with ultrastructural analyses (SEM and TEM) and FISH experiments. Raman microspectrometry was used in order to detect elemental sulfur within the samples and, by extrapolation, the involvement of thiotrophic organisms in this symbiosis.

\section{Materials and Methods}

\section{Sampling site}

Individuals of Pseudovorticella sp. were collected from different sunken leaves of Rhizophora mangle (Rhizophoraceae) covering the marine sediment in the mangrove lagoon "Manche à Eau" $\left(16^{\circ} 16^{\prime} 33.61^{\prime \prime} \mathrm{N}, 61^{\circ} 33^{\prime} 18.09^{\prime \prime} \mathrm{W}\right)$ in Guadeloupe, French West Indies. The samples were collected on the same day and were prepared for the different analyses.

\section{Light microscopy}

Several pseudovorticellid individuals were collected from the same sunken leave and observed with a stereomicroscope and an Eclipse 80i Nikon microscope. Photographs were taken using respectively a Canon EOS 70D and a Nikon DXM $1200 \mathrm{~F}$.

\section{Ultrastructural analyses}

Small fragments of sunken leaves presenting several pseudovorticellid individuals fixed on the surface were observed, 
and collected using a scalpel blade under the light of a stereomicroscope before preparation for scanning electron microscopy (SEM) and transmission electron microscopy (TEM) investigations.

Samples for SEM were fixed in $0.22 \mu \mathrm{m}$-filtered $4 \%$ paraformaldehyde solution in seawater at $4{ }^{\circ} \mathrm{C}$. They were then dehydrated in graded concentrations of acetone, critical point dried in $\mathrm{CO}_{2}$ and sputter-coated with gold before observation with a FEI Quanta 250 running at $20 \mathrm{kV}$ (Abouna et al. 2015; Jean et al. 2015).

For TEM observations, individuals of Pseudovorticella sp. were prefixed at $4{ }^{\circ} \mathrm{C}$ in $2.5 \%$ glutaraldehyde in $0.1 \mathrm{M} \mathrm{pH} \mathrm{7.2}$ cacodylate buffer adjusted to $900 \mathrm{mOsm}$. After a brief rinse in the same buffer, they were fixed for $45 \mathrm{~min}$ at room temperature in $1 \%$ osmium tetroxide in the same buffer, rinsed in distilled water and post-fixed with $2 \%$ aqueous uranyl acetate for $1 \mathrm{~h}$ at room temperature. Samples were dehydrated in graded concentration of acetone before embedding in epoxy resin and observation in a FEI Tecnai F20 running at $200 \mathrm{kV}$ (Abouna et al. 2015; Gros et al. 2012).

\section{Raman spectrometry analyses}

10 individuals were deposited on a circled section of a slide and were directly analyzed in seawater. The samples were preliminary fixed in $2 \%$ paraformaldehyde in filtered seawater $(0.22 \mu \mathrm{m})$ and washed in sterile seawater before analysis. Seawater constitutes both an isotonic medium for marine ciliates and a good cooling medium to avoid irradiation damages of the samples during Raman analyses. Spectra were recorded using a Raman microspectrometer HRevo Horiba using a $514.5 \mathrm{~nm}$ exciting line delivered by an argon ion laser. The samples were deposited on a silanized slide to prevent the movement of organisms during the analysis. After detection of specific bands of elemental sulfur $\mathrm{S}_{8}$ in spectra recorded on the sample, a complete mapping of the studied individual was acquired following the method developed in previous works by Himmel et al. (2009), in order to investigate the sulfur distribution in the zooid. The laser power at the sample surface was $105 \mu \mathrm{W}$ and spectra acquisition time $10 \mathrm{~s}$.

\section{DNA extraction and amplification}

A total of 100 individuals were collected on the same day directly from a couple of sunken leaves. DNA from protists was extracted using DNeasy Blood and Tissue kit (Qiagen) according to manufacturer's instructions. The genes encoding for $16 \mathrm{~S}$ rRNA and $18 \mathrm{~S}$ rRNA were amplified using respectively universal primer sets 8F/1492R (Lane 1991; Lane et al. 1986) and 1F/5R (Giribet et al. 1996). PCR amplifications were performed as follows: $94^{\circ} \mathrm{C}$ for $5 \mathrm{~min}, 30$ cycles of $94{ }^{\circ} \mathrm{C} 1 \mathrm{~min}, 55^{\circ} \mathrm{C} 30 \mathrm{~s}, 72^{\circ} \mathrm{C} 90 \mathrm{~s}$ and finally $72^{\circ} \mathrm{C}$ for $7 \mathrm{~min}$. PCR products were purified using QIAquick PCR purifica- tion Kit (Qiagen) and were fully sequenced by Genoscreen (http://www.genoscreen.com).

\section{Phylogenetic analysis of 16S rRNA and 18S rRNA gene sequences}

Phylogenetic analyses of $16 \mathrm{~S}$ rRNA and 18S rRNA gene sequences were obtained directly from PCR amplification products. Then, the sequences were compared with the National Center of Biotechnology information NCBI (http://www.ncbi.nlm.nih.gov) database using BLAST. Best hits were included in phylogenetic analyses. Sequences were aligned using MUSCLE and alignments were checked manually. Regions of ambiguous or uncertain alignment were eliminated from consideration (Abouna et al. 2015). Phylogenetic analyses were performed using the programs MEGA version 7 (Kumar et al. 2016). The phylogenetic tree was constructed from the multiple-aligned data using the Maximum Likelihood (ML) method with TamuraiNei as genetic distance model. Nodes robustness was assessed by performing 1000 bootstrap replicates, and only bootstrap values above $50 \%$ are indicated at the nodes of the trees (Abouna et al. 2015). Following analysis, the 18S rRNA and 16S rRNA gene sequences obtained in this study were then deposited in the GenBank database under no. KY777484 and KY777480 respectively.

\section{Fluorescent in situ hybridization (FISH) experiments}

Pseudovorticella sp. samples were fixed for FISH in $4 \%$ paraformaldehyde in sterile seawater at $4{ }^{\circ} \mathrm{C}$. After two washes in sterile seawater, samples were dehydrated in graded concentration of ethanol (10 min per bath). Dehydratation of samples with pure ethanol is very important because of the presence of sulfur in the samples that may generate autofluorescence. Sulfur is dissolved by ethanol during dehydratation process. Before hybridization experiments, samples were partially rehydrated in a reverse ethanol series to ethanol $70 \%$ in distilled water and deposited on silanized slides. After drying, the slides were incubated for $12 \mathrm{~min}$ in $0.2 \mathrm{M}$ $\mathrm{HCl}$, rinsed for $10 \mathrm{~min}$ in prehybridization buffer $(20 \mathrm{mM}$ Tris- $\mathrm{HCl}[\mathrm{pH} 8.0])$, incubated for $5 \mathrm{~min}$ at $37^{\circ} \mathrm{C}$ in $0.5 \mathrm{mg} \mathrm{ml}^{-1}$ of proteinase $\mathrm{K}$ (Sigma) in prehybridization buffer and rinsed in the same prehybridization buffer. Hybridizations were carried out all night long at $46{ }^{\circ} \mathrm{C}$ in hybridization buffer $(0.9 \mathrm{M} \mathrm{NaCl}, 0.02 \mathrm{M}$ Tris- $\mathrm{HCl}$ buffer (pH 7.8), 0.01\% SDS). Positive and negative hybridization controls were respectively EUB338 (Amann et al. 1990), targeting most members of the Bacteria and NONEUB338 (Wallner et al. 1993). Two specific pseudovorticellid symbiont probes (labelled with Cya3) were designed according to $16 \mathrm{~S}$ rRNA bacterial sequence obtained in this 


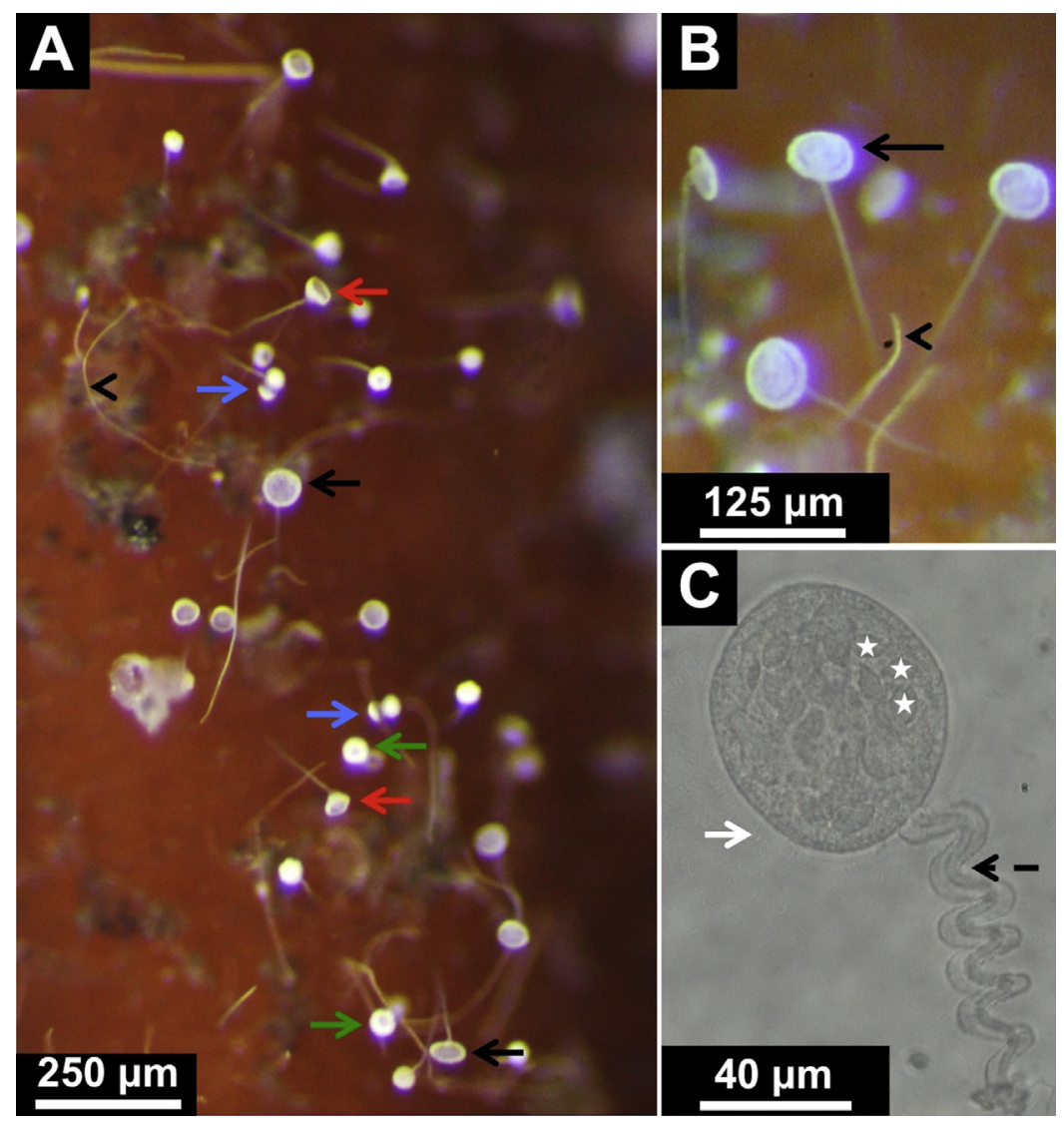

Fig. 1. Light micrograph of Pseudovorticella sp. (A-B) Individuals attached to sunken leaf of Rhyzophora mangle (stereomiscroscope). Black arrows mark fully extended zooids, red arrows mark zooids during extension and green arrows mark contracted zooids. Blue arrows indicate individuals exhibiting two zooids attached to the stalk (asexual reproduction) and arrowheads denote free-living filamentous bacteria. These organisms appeared white under incident light. (C) Stars indicate vacuoles in the cytoplasm, black broken arrow shows the stalk with the spasmoneme and white arrow denotes bacteria (microscope).

study: VO16 B (5'-CGTCATCATCTTCCCAACTGAAAG$\left.3^{\prime}\right)$ was designed using the online Primer3 internet based interface (Rozen and Skaletsky 2000) and VORTI (5'-ASCAGACTCTAGTCAGCCA-3') was modified from ZIS645 probe (Schuster and Bright 2016). Probe 16S ssrRNA localization was optimized according to Fuchs et al. (1998). The probe's specificity was further tested with the online Probes Match tool provided by the Ribosomal Database Project (Cole et al. 2005) and have shown that VO16 B probe is less specific than VORTI probe (respectively 356 hits and 0 hit without mismatch allowed and 1624 hits and 70 hits with 1 mismatch allowed). Optimal hybridization conditions for the newly designed specific probes VO16B and VORTI were determined by applying a series of formamide concentrations $(0-40 \%)$ in the hybridization buffer in order to reach the best signal intensity, directly related to bound probes. Slides were mounted with VECTASHIELD ${ }^{\circledR}$ fluorescent mounting medium with DAPI (VECTOR, USA) and visualized under an epifluorescence microscope Eclipse 80i (Nikon, France) and a confocal microscope Leica SPE II.

\section{Results}

The host Pseudovorticella sp.

\section{Morphology}

According to microscopic observations, individuals appeared white under incident light. Zooid disc-shaped when fully extended, bell-shaped during extension (Fig. 1A, B) and roundish to ellipsoidal when contracted (Fig. 1C), about $40-50 \mu \mathrm{m}$ in diameter. Peristomial lip wide, flattened, with a falling edge when zooid fully extended (Fig. 1A, B). Helicoidal stalk with variable length, usually about $100 \mu \mathrm{m}$ long when contracted, and $200 \mu \mathrm{m}$ when extended, $6 \mu \mathrm{m}$ in diameter (Fig. 1A-C). Spasmoneme approximately $2-3 \mu \mathrm{m}$ in diameter (Fig. 1C). Macronucleus J-shaped and band like, extended in spiral through whole cell (pers. obs. based on DAPI staining). Micronucleus not observed. Cytoplasm colourless or greyish with many spherical vacuoles, about $5 \mu \mathrm{m}$ in diameter, containing bacteria (Fig. 1C). Ciliature has not been investigated. 

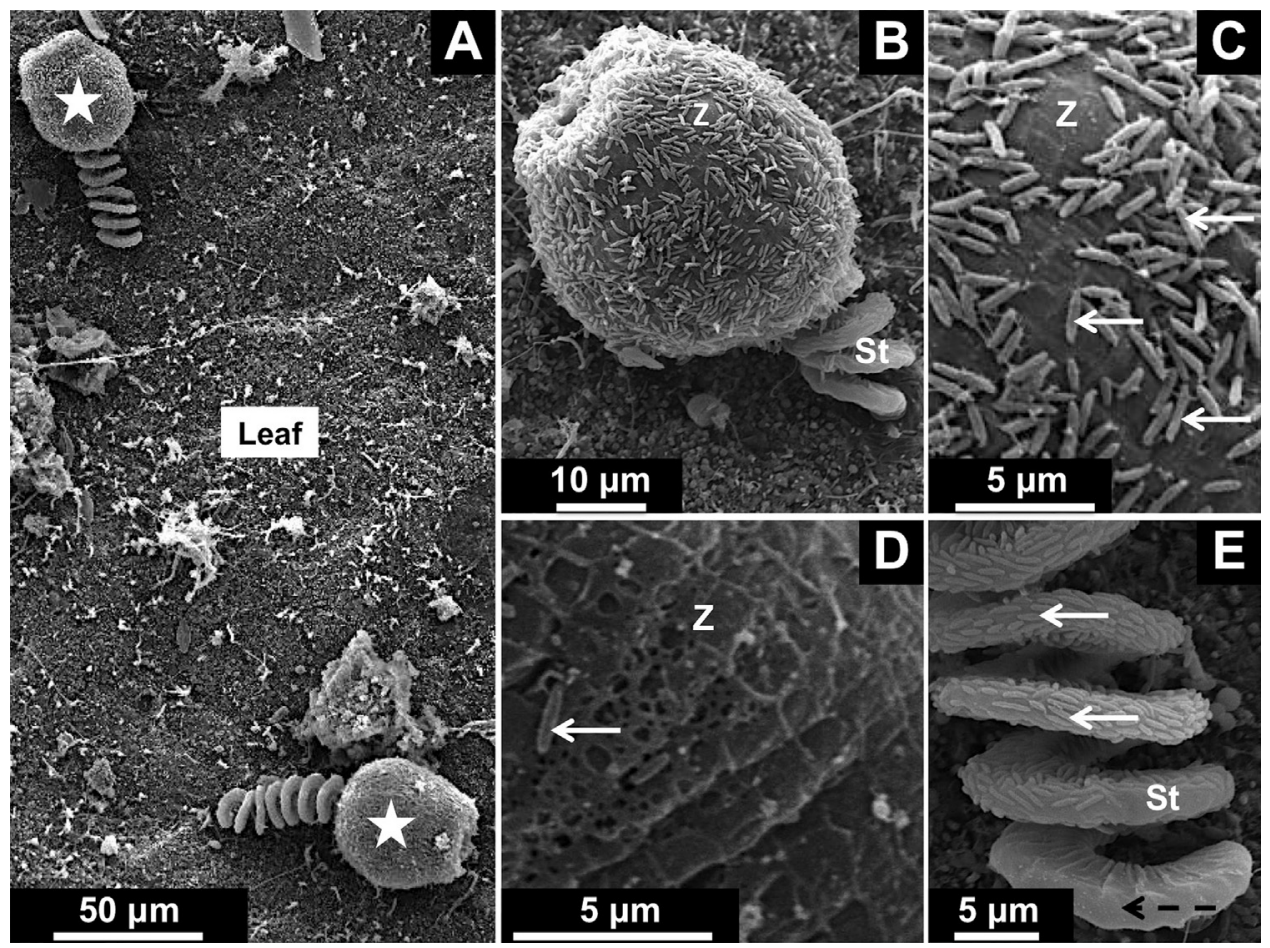

Fig. 2. Scanning electron micrographs of Pseudovorticella sp. (A) Stars mark individuals attached to sunken leaf of Rhyzophora mangle. (B-E) White arrows show bacteria covering the entire surface of the zooid (Z) and only partially the stalk (St). The reticulate silverline system is partially hidden by bacteria on the images $\mathbf{C}$ and clearly visible on the image $\mathbf{D}$. Black broken arrow shows the basal part of the stalk free of bacteria.

\section{Scanning electron microscopy (SEM)}

This organism consists of a roundish to ellipsoidal zooid when contracted and a helically contracted stalk with smooth surface (Fig. 2A, B). The reticulate silverline system is partially hidden by the bacteria coat (Fig. 2A, B), but visible in Fig. 2C, D. The reticulate silverline system, which represents the pattern of pellicular ridges on the surface of the zooid, is characteristic of the Pseudovorticella genus. The basal part of the stalk is anchored into the leaves (Fig. 2A, E).

\section{Molecular identification and phylogenetic analyses of the host}

The 18S rRNA gene sequence obtained for the host had a total length of 1005 nucleotides. The most closely related sequence which is recovered from Vorticella sp. FG-2015 voucher (Accession number: KM222117) displayed 98\% identical positions with the sequence obtained in this study. The phylogenetic reconstruction based on partial sequences of the gene coding for 18S rRNA placed this mangrove ciliate colonizing sunken woods within the Peritrichia and more specifically within the Vorticella group which is close to other ciliates that have a stalk that contracts in a spiral fashion (Fig. 3). However, this ciliate and Vorticella sp. FG-2015 clustered in a clade with a low-robustness node separated from the other Vorticella sequences. Regarding to morphological features and phylogenetic analysis, the peritrich is very likely a member of the genus Pseudovorticella.

\section{Ectosymbiont of Pseudovorticella sp.}

\section{Scanning electron microscopy}

Bacteria largely cover the body of Pseudovorticella sp. forming a single layer like a bacterial coat (Fig. 2B). Bacteria on stalk and zooid rod shaped, $\sim 2 \mu \mathrm{m}$ long and $\sim 0.6 \mu \mathrm{m}$ wide (Fig. 2B-E), irregularly arranged on the zooid and aligned on the stalk. Only adhesive disc and basal, noncontractile part of the stalk are devoid of bacteria (Fig. 2E).

\section{Molecular identification and phylogenetic analyses of the associated ectosymbiont}

The 16S rRNA gene sequence obtained for the ectosymbiont had a total length of 1320 nucleotides. The phylogenetic tree based on partial sequences coding for 16S rRNA gene, revealed that the symbiont of the peritrich Pseudovorticella $\mathrm{sp}$. is related to $\gamma$-proteobacteria already known as symbionts of various marine invertebrates (Fig. 4). The most closely related sequence which is recovered from the ectosymbiont 


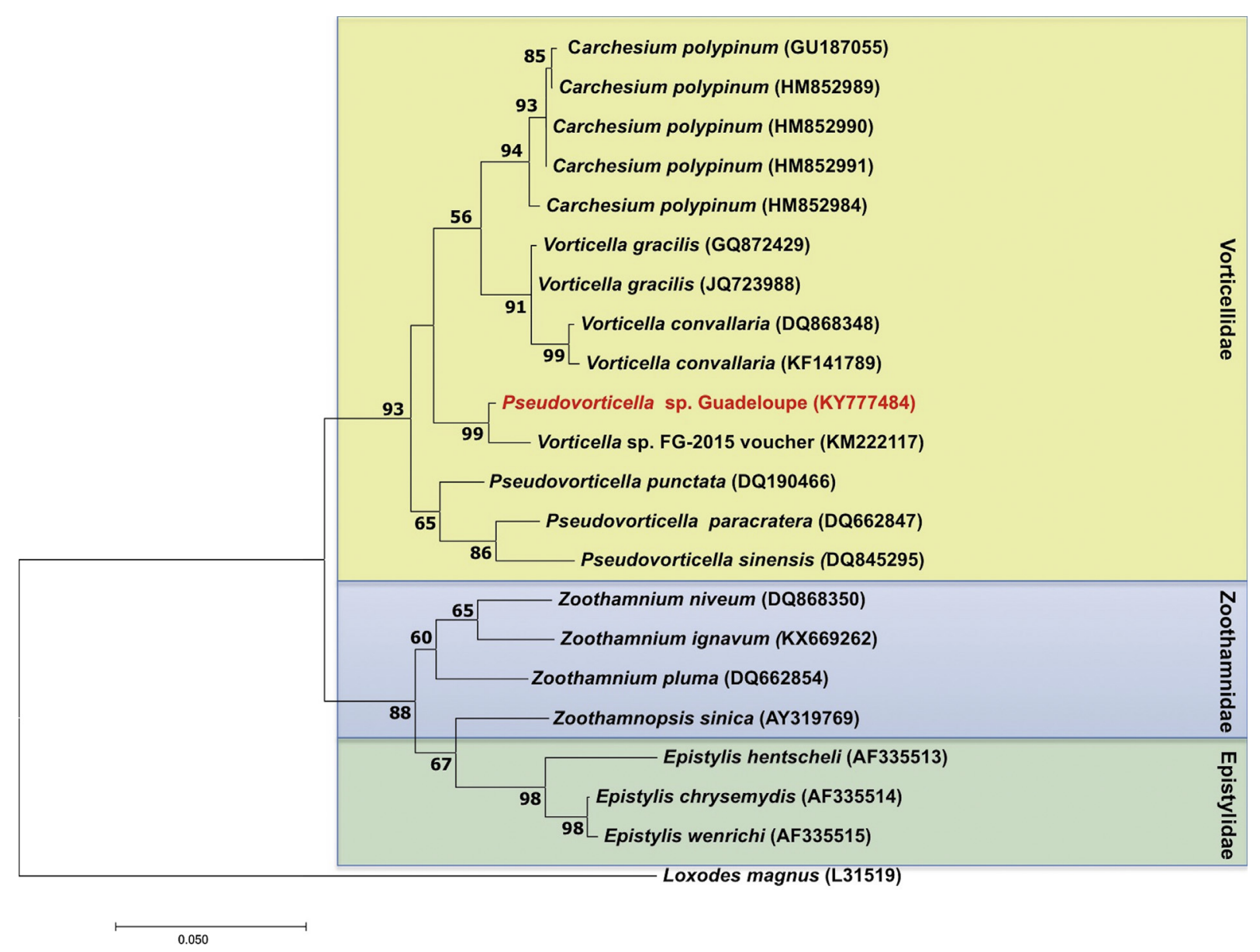

Fig. 3. Phylogeny based on $18 \mathrm{~S}$ rRNA gene sequences from pseudovorticellid colonizing sunken woods in mangrove. Maximum likelihood (ML) tree displaying the phylogenetic relationships between Pseudovorticella sp. with other ciliate species based on the analysis of partial 18S rRNA gene sequences of 781 nucleotides. Loxodes magnus was used as outgroup. Only bootstrap values higher than $50 \%$ are shown. The scale bar corresponds to 5 changes per 100 nucleotides.

of Zoothamnium ignavum named Candidatus Navis piranensis (Accession number: KX669263), displays 97\% identical positions with the sequence obtained in this study.

\section{Fluorescent in situ hybridization analyses}

The Fluorescent in situ Hybridization experiment with the specific probes VO16B (Fig. 5A, B) and VORTI (Fig. 5D, F) designed from $16 \mathrm{~S}$ rRNA sequence confirmed that the sequence used for the phylogenetic analysis came from the ectosymbionts. The optimal formamide concentration in the hybridization buffer was found to be $20 \%$ for both specific probes. At a concentration of $40 \%$ formamide the amount of bound probe was slightly decreased resulting in a decrease of the signal. According to confocal observations (Fig. 5B, C), bacterial ectosymbionts that cover the entire body of Pseudovorticella sp. are the same as those found in the food vacuoles. For each specific probe used, the FISH signal was confirmed by the positive signal of EUB338 probe (Fig. 5C, G). The application of probe NON-EUB338 (complementary to bacterial probe EUB338) as a negative control yielded no detectable fluorescence signal (Fig. 5E), demonstrating that signals were not caused by autofluorescence or unspecific staining of the bacteria but rather by specific binding of the probes. According to FISH observations, ectosymbiotic bacteria are detached from the surface of zooid and are ingested by the host during the nutrition process. Bacteria are stored in the food vacuoles where they should be digested.

\section{Transmission electron microscopy}

Bacteria found on the surface of the zooid and the stalk organized in a single layer (Fig. 6A). Food vacuoles contain bacteria (Fig. 6A, B). Bacteria also present in the vestibule of the protist (Fig. 6A). These bacteria are similar to those observed on zooid and stalk surface and have the double membrane characteristic of Gram-negative bacteria (Fig. 6B). White spots within bacterial's cytoplasm (Fig. 6B) correspond to the print left by sulfur granules. 


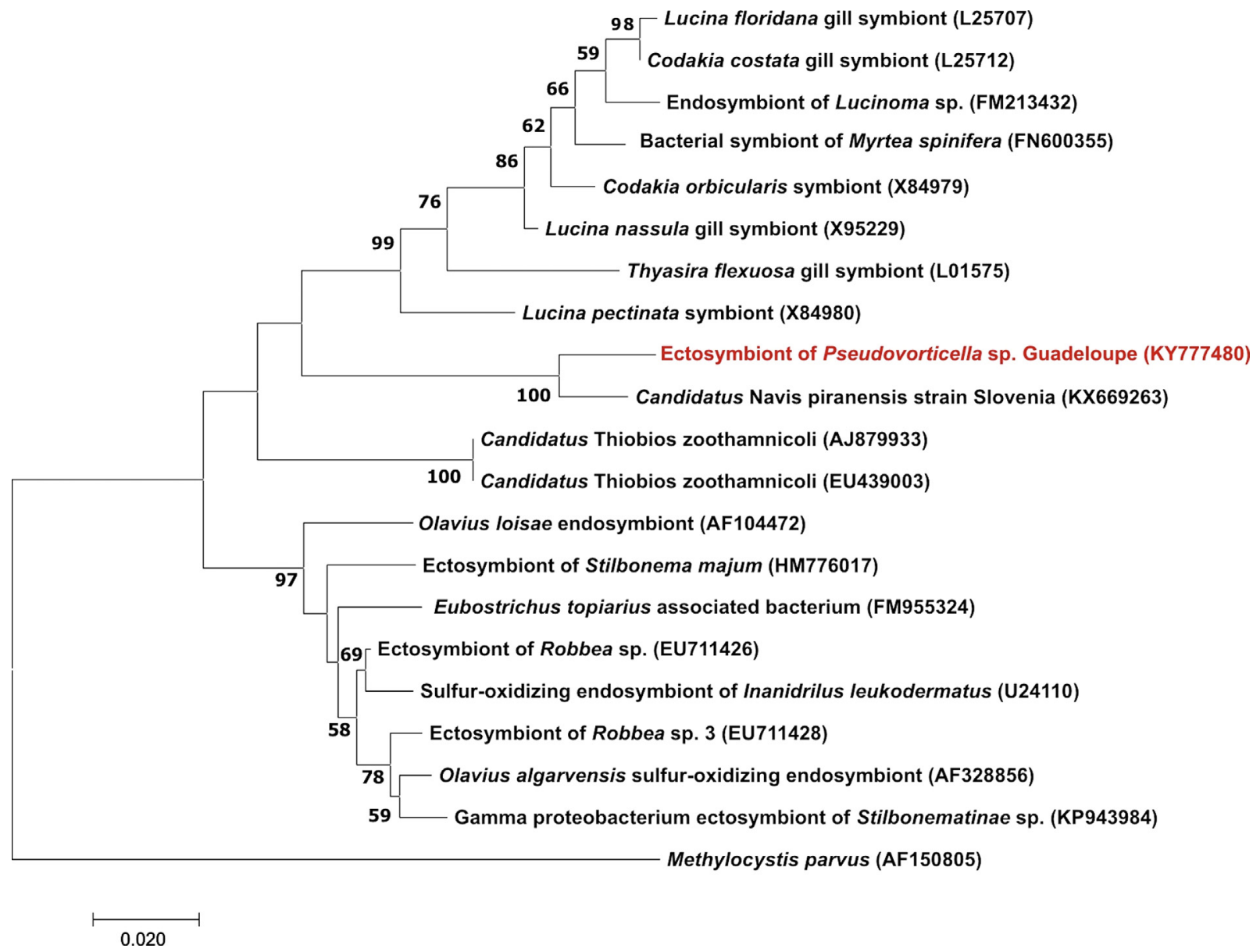

Fig. 4. Phylogeny based on $16 \mathrm{~S}$ rRNA gene sequences from bacterial symbionts associated with pseudovorticellid colonizing sunken woods in mangrove. Maximum likelihood (ML) tree displaying the phylogenetic relationships between the Pseudovorticella sp. ectosymbiont with other endo- and ecto-symbionts sulfur-oxidizing bacteria based on the analysis of 16S rRNA gene sequences of 1233 nucleotides. Methylocystis parvus was used as outgroup. Only bootstrap values higher than $50 \%$ are shown. The scale bar corresponds to 2 changes per 100 nucleotides.

\section{Raman spectrometry analyses}

Observations of Pseudovorticella sp. with the light microscope show the presence of white spots (Fig. 7A). The spectra recorded onto these spots revealed the presence of elemental sulfur $\mathrm{S}_{8}$ in the zooid whereas no sulfur was detected in the surrounding water and on the stalk (Fig. 7B). According to sulfur mapping realized on the zooid (Fig. 7C) and previous results, the sulfur is mainly concentrated in the cytoplasm of bacteria contained in the food vacuoles of the ciliate whereas no sulfur was detected on its surface.

\section{Discussion}

Many species of the genus Pseudovorticella are common ciliates living in marine ecosystems (Ji et al. 2003, 2006; Sun et al. 2006, 2013, 2017). Pseudovorticella sp. was observed several times in Guadeloupe's mangrove, but despite a suspicion of symbiosis based on ultrastructural analyses (Laurent et al. 2009, 2013; Maurin et al. 2010) the relationship has never been clearly defined. SEM and TEM observations have already shown the presence of ectosymbiotic bacteria covering the body surface of Pseudovorticella sp. colonizing mangrove wood falls (Laurent et al. 2009, 2013; Maurin et al. 2010). Similar results were observed in the solitary Vorticella sp. and the colonial Zoothamnium niveum growing at point sources of $\mathrm{H} 2 \mathrm{~S}$ from mangrove peat in the Belize Barrier Reef system and leaf debris in the western Mediterranean (Ott et al. 2004). This can be explained by genetic proximity of these organisms but also by their lifestyle. Indeed, being already phylogenetically related, these organisms grow on the same substratum and it is not uncommon to find them together on the same sunken leaves. Recently, a symbiosis occurring between a ciliate species of Zoothamnium, and a novel genus of bacteria proposed as "Candidatus Navis piranensis" was found from shallow-water sunken wood in the North Adriatic Sea (Schuster and Bright 2016). The phylogenetic analyses carried on present Pseudovorticella sp. have shown that these two ciliates, although geographically distant, shared similar ectosymbiotic bacteria. However, only the dominant bacterium has been identified during this study. Thus, the 

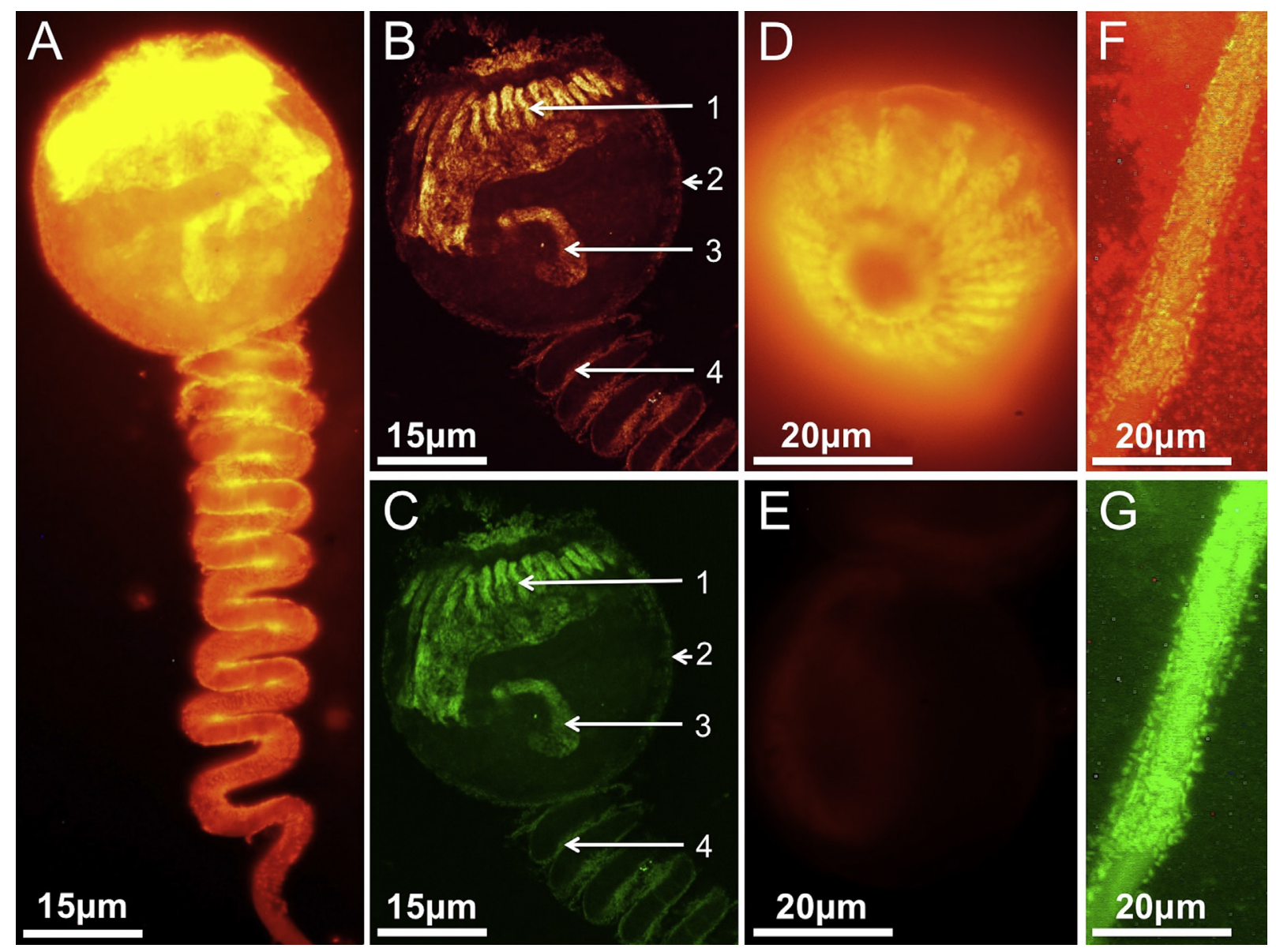

Fig. 5. Fluorescent in situ hybridization analysis. (A) Hybridization of ectosymbionts using the probe VO16B showing hybridized bacteria covering the entire body of Pseudovorticella sp. (B) According to confocal microscopy, the ectosymbiont specific probe VO16B strongly hybridized the bacteria present on the peristome and in the buccal cavity (1), at the surface of the zooid (2), within the food vacuoles (3), and on the stalk (4). (C) Signals were confirmed thanks to EUB338 probe. (D) Ectosymbionts on the zooid and around the peristome of Pseudovorticella sp. were strongly hybridized with the specific probe VORTI. (E) No signal was detected from ectosymbionts on the zooid of Pseudovorticella sp. using NON-EUB338 probe. (F, G) Ectosymbionts on the stalk of Pseudovorticella sp. were strongly hybridized with the respective VORTI and EUB338 probes.

potential strain heterogeneity occurring in this epibiosis was not investigated. According to phylogenetic analysis of the host, members of the family Vorticellidae form a monophyletic group, including Pseudovorticella, Vorticella and Carchesium species. Similar results were obtained by Li et al. (2008). All members of this group have a helically twisted contracted spasmoneme (Lynn 2008). The genus Pseudovorticella was established by Foissner and Schiffmann (1974) for peritrichs that are morphologically similar to Vorticella (i.e. solitary zooids that are borne upon a non-branching stalk that contracts in a spiral fashion), but that have a reticulate silverline system. The silverline system, which represents the pattern of pellicular ridges on the surface of the zooid, may be either transverse (i.e. Vorticella spp.) or reticulate (i.e. Pseudovorticella spp.) and was suggested to be a genuslevel character for sessilids (Foissner and Schiffmann 1974). According to SEM observations, the zooid has a reticulate silverline system, and thus, this ciliate is likely a member of the genus Pseudovorticella. However, phylogenetic analysis using ML method placed this ciliate within the Vorticella group, while NJ method placed this ciliate within the Pseudovorticella group (data not shown). The genus Pseudovorticella comprises more than 20 species, most of which have been transferred from Vorticella after a first misidentification (Foissner 1979; Foissner and Schiffmann 1974; Foissner et al. 1992; Leitner and Foissner 1997; Song and Warren 2000; Warren 1986, 1987). Although the split is now supported by molecular data, SSU rRNA gene is not always reliable in separating taxa at specie-genus level of Vorticellidae ( $\mathrm{Li}$ et al. 2008). Thus, this suggests that the silverline system is probably more informative than SSU rRNA gene for determining genus-level phylogenetic relationships among vorticellids. A second split using the number of epistomial membranes as a main distinguishing feature was proposed then by Foissner et al. (2009). Some analyses still have to be performed in order to characterize more precisely the host, although the results suggest that this organism belongs to Pseudovorticella. Good descriptions usually demand at 


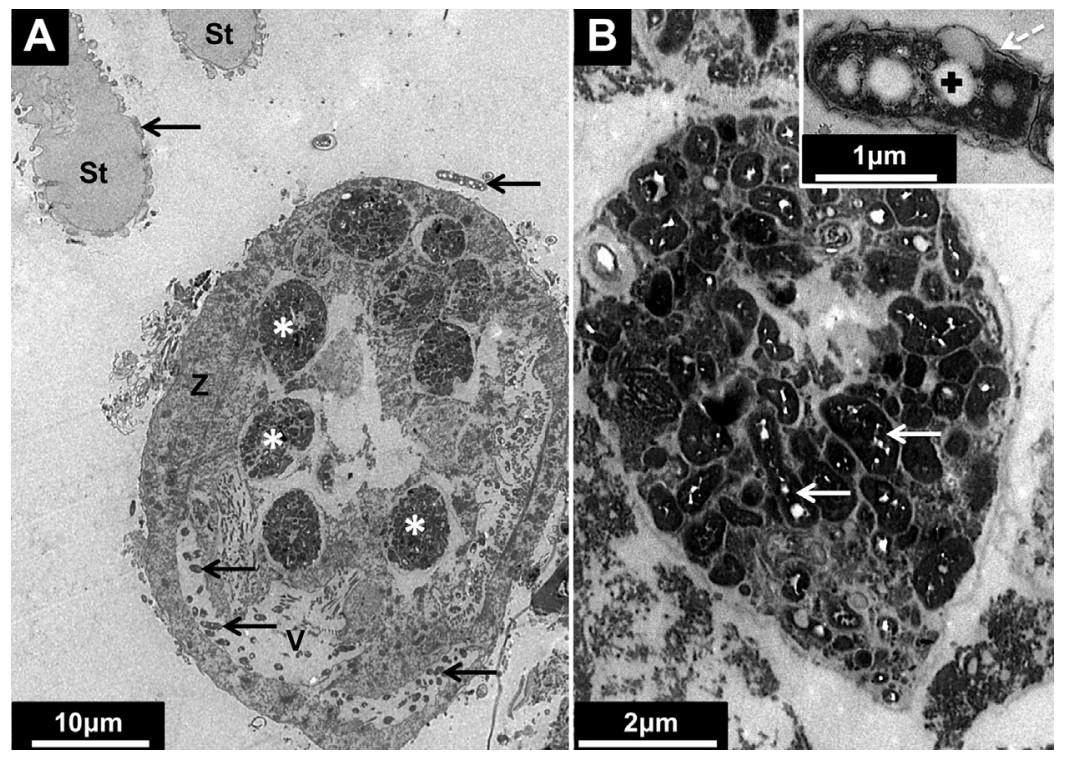

Fig. 6. Ultrastructural analysis of Pseudovorticella sp. by TEM. (A) Black arrows denote the bacteria at the surface of the zooid (Z), on the stalk (St) and in the vestibule (V). In the cytoplasm, food vacuoles indicated by asterisks, contain ingested bacteria. (B) Food vacuole at high magnification containing similar bacteria in shape to those observed at the surface of the protist. Black cross indicates white granules located within the bacteria whereas white broken arrow shows the double membrane characteristic of Gram-negative bacteria.
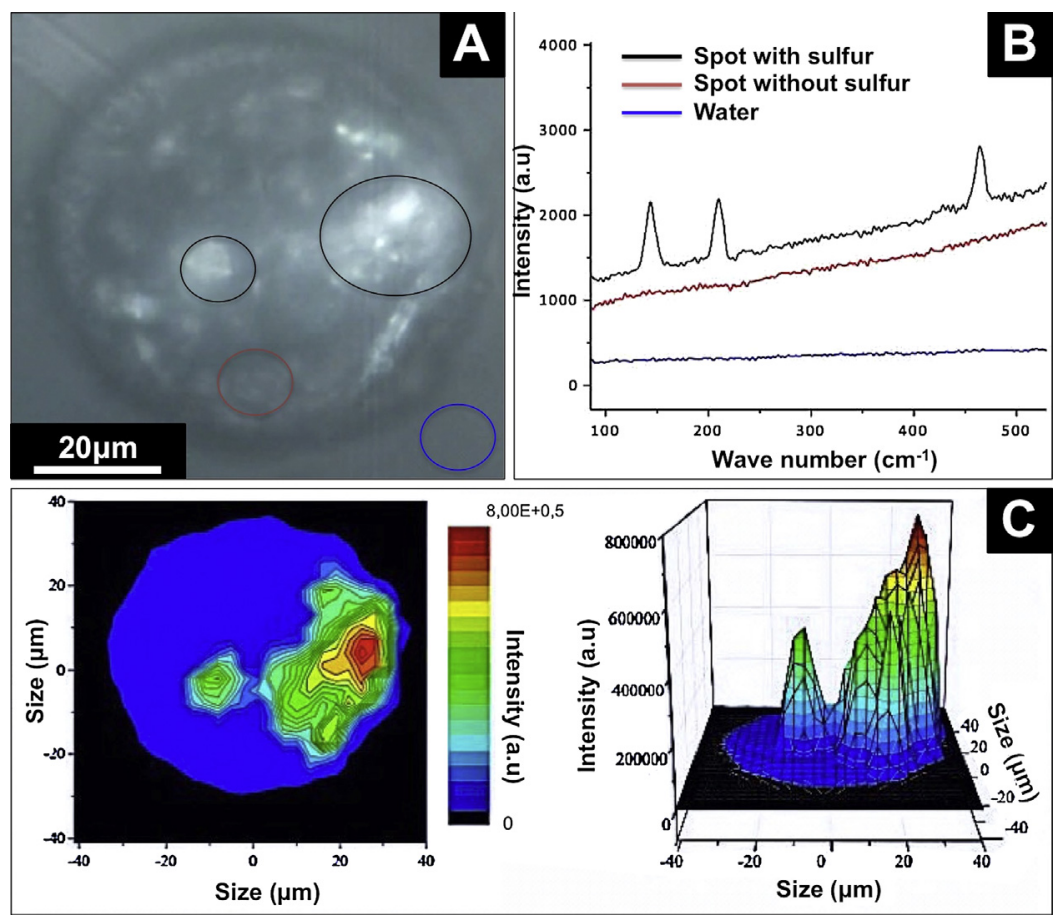

Fig. 7. Analysis of Pseudovorticella sp. by Raman microspectrometry. (A) Light micrograph of the zooid. Black circles indicate few white spots suspected to contain elemental compounds whereas other spots indicate by red circle seem to be free of those compounds. Blue circle corresponds to the surrounding water. (B) Raman spectra acquired from this individual. Black line represents pure elemental sulfur $\mathrm{S}_{8}$ detected in the white spot, which is characterized by two peaks at $480 \mathrm{~cm}^{-1}$ and $210 \mathrm{~cm}^{-1}$. Red line confirms the absence of sulfur in the spot suspected to be free of sulfur. Blue line shows that the surrounding seawater (used as negative control) as well as the periphery of the protist remain free of sulfur, the Raman spectrum showing no peak. (C) 2D and 3D mapping (respectively left and right pictures) show that sulfur is located within the white spots observed in Pseudovorticella sp. individual. A high intensity corresponds to a detection of a high sulfur spot. (For interpretation of the references to color in this figure legend, the reader is referred to the web version of this article.) 
least live observations, silver nitrate and protargol or silver carbonate impregnation (Foissner 2014).

The contractile stalk allows these organisms to remain fixed in the substratum and contribute to the mixing of oxygenated and deoxygenated $\mathrm{H}_{2} \mathrm{~S}$-containing seawater within the substrate-seawater boundary layer, thanks to rapid contractions and slow extensions (Vopel et al. 2002). The stalk elevates the zooid whose peristomial cilia transport seawater, which is filtered for suspended particles (Vopel et al. 2002). The zooid is the filtration device of the organism, the beating of peristomial cilia creates a flow of water which forms toroidal vortices that carry the food inside the body (Vopel et al. 2001). Microscopic observations have also shown the presence of bacteria in the vestibule corresponding to the buccal cavity and in the food vacuoles. The presence of bacteria in these different parts of this organism clearly indicates the way followed by bacteria during their ingestion. Ciliates feed primarily on bacteria; bacteria are transported in the vestibule thanks to the flow of water created by the cilia and are then stored in food vacuoles after crossing the cytostome and the cytopharynx. Detachment of the bacteria occurs mostly during contraction because of the high water velocity around the zooid and the rapid movement of the cells (Vopel et al. 2002). Moreover, the contraction of the zooid decreases the surface available to bacteria which result in detachment (Vopel et al. 2002). Bacteria found in the food vacuoles are probably not a symbiosis but rather the result of the nutrition process in which ectosymbiotic bacteria are ingested, stored in the digestive vacuoles before to be potentially digested. Despite their small numbers, other bacteria were found in the food vacuoles during FISH observations based on non-overlapping of EUB 338 and specific probes (pers. obs.). Similar results were observed for Z. niveum (Rinke et al. 2007) and Z. ignavum (Schuster and Bright 2016). This is not surprising because during the process of nutrition, other bacteria present in the surrounding water may also be trapped in the vortex produced by the beating of cilia. The presence of ectosymbiotic bacteria in feeding and digestive vacuoles has also been reported for protist belonging to the genus Kentrophoros (Fenchel and Finlay 1989) and Zoothamnium (Bauer-Nebelsick et al. 1996a; Schuster and Bright 2016). However, most of bacteria contained in food vacuoles have the same characteristic ultrastructure as the symbionts (Bauer-Nebelsick et al. 1996b; Vopel et al. 2002). We observed similar results in Pseudovorticella sp. Fish experiments have confirmed that bacteria covering the surface of the zooid and those found in food vacuoles are the same. TEM observations have shown the presence of sulfur granules located within the bacteria found in the food vacuoles and on the zooid, as well as the double membrane characteristic of Gram-negative bacteria. The same results were found from Candidatus Thiobios zoothamnicoli (BauerNebelsick et al. 1996b) and Cladonema sp. ectosymbiont (Abouna et al. 2015). Although the metabolic abilities of these new ectosymbiotic bacteria have to be further studied, the results suggest a thiotrophic metabolism.
One of the ways in which symbiosis benefits to protists is to ensure the presence of food for the protist, either by cultivation of the symbiont as an actual food source, or by using products derived from the symbiont for nutrition (Gast et al. 2009). Digestion of ectosymbiotic bacteria and assimilation of organic molecules produced by chemosynthesis sustain the host's needs in carbon (Volland, pers. comm). The transfert of labelled carbon from the $\mathrm{C}$ fixation by the symbionts to the host has already been shown for $Z$. niveum by Rinke (2002). Mangrove sediment and wood falls are able to sustain development of thiotrophic symbioses thanks to production of sulfur due to organic matter degradation (Laurent et al. 2013; Ott et al. 2004). Sulfidic concentration from wood falls degradation in mangrove has been measured in the past by Laurent et al. (2009). This production of sulfur ensures the presence of sulfur-oxidizing bacteria that constitute an important food source in some shallow continental shelf systems (Montagna and Spies 1985; Pascal et al. 2014; Powell et al. 1983). In mangrove ecosystems, trophic resource constituted by Beggiatoa mats (Jean et al. 2015) does not affect the general food web structure, meio- and macrofaunal abundances or the contribution of bacteria to their diet (Pascal et al. 2014). Ectosymbiosis could be an excellent process for the host to ensure its nutrition while being able to colonize new habitats. In this study, Raman spectrometry was used to identify sulfur $\mathrm{S}_{8}$ species and investigate its distribution in Pseudovorticella sp. according to a method previously used (Himmel et al. 2009; Maurin et al. 2010). This technique, particularly efficient for sulfur detection, is applied in order to detect a thiotrophic metabolism in the symbiotic organisms. This technique looks to be more effective and less restrictive than methods frequently used (EDXS, EELS). Indeed, these techniques are time consuming, expensive and require technical skills (Himmel et al. 2009). Moreover, the non destructive character of Raman microspectrometry allows us to recover the sample after Raman experiments in order to carry out complementary analytical, enzymological, and ultrastructural (i.e. TEM, SEM, immunochemistry) studies (Maurin et al. 2010). The spots appearing white under light microscopy are targeted primarily due to their nature and sizes, $\mathrm{S}_{8}$ aggregates scatter light. Our results have shown the presence of $\mathrm{S}_{8}$ sulfur granules in the cytoplasm of ectosymbiotic bacteria stored in food vacuoles of Pseudovorticella sp. However, due to the spatial resolution of the Raman microscope $(4 \mu \mathrm{m})$, it is not possible to determine the precise location of sulfur in the bacteria at the ultrastructural level. Sulfur location requires TEM analysis (Himmel et al. 2009). Nevertheless even a $4 \mu \mathrm{m}$ resolution allow detection and characterization of the speciation of sulfur and its location at mesoscale within a very short time. Raman spectra acquired on the bacteria present at the surface of the zooid do not reveal the presence of $S_{8}$ species. This can be explained either by a $\mathrm{S}_{8}$ concentration inferior to the detection limit or more probably by the fact that those bacteria can contain elemental sulfur in a different form than $\mathrm{S}_{8}$ (highly Raman active). In the latter case, the precipitation of sulfur into $S_{8}$ phase will 
occur during the digestion process by the ciliate resulting in the presence of $\mathrm{S}_{8}$ agregates detected in the food vacuoles. According to Raman spectrometry, TEM observations and phylogenetic analyses the symbiont of Pseudovorticella sp. likely oxidizes sulfur like many other thiotrophic organisms present in this environment but these results need to be confirmed by the analysis of APS reductase and RubisCo gene. These two enzymes are involved respectively in sulfuroxidizing pathway and Calvin-Benson cycle of $\mathrm{CO}_{2}$ fixation and could be used for the identification of sulfur-oxidizing symbiont (Duperron et al. 2009; Herry et al. 1989).

\section{Conclusion}

This study uncovers a new potential sulfur-oxidizing symbiosis involving a peritrich ciliate and ectosymbiotic sulfur-oxidizing bacteria. This is the second case of ectosymbiosis involving a peritrich ciliate in mangrove ecosystem. Pseudovorticella sp. Guadeloupe and Zoothamnium niveum are found frequently attached on the same substrate and have very similar behaviors regarding their lifestyle and nutrition. Despite, the fact that these ciliates harbour different ectosymbiotic bacteria, the two relationships are clearly ectosymbiotic associations in which the symbionts are cultivated by their host for nutritional purposes. The symbiont may also be involved in a detoxification mechanism, oxidizing sulfides into elemental sulfur and finally to sulphate. Because of the high sulfides concentration recorded in this environment. The present study sheds light on a diversity of microorganisms living in symbiosis still underestimated in these mangrove ecosystems.

\section{Acknowledgements}

A.G. is funded as PhD Student by the Region Guadeloupe grant and the society Hygiene Outremer.

\section{References}

Abouna, S., Gonzalez-Rizzo, S., Grimonprez, A., Gros, O., 2015. First description of sulphur-oxidizing bacterial symbiosis in a cnidarian (Medusozoa) living in sulphidic shallow-water environments. PLoS One 10, e0127625.

Amann, R.I., Binder, B.J., Olson, R.J., Chisholm, S.W., Devereux, R., Stahl, D.A., 1990. Combination of 16S rRNA-targeted oligonucleotide probes with flow cytometry for analyzing mixed microbial populations. Appl. Environ. Microbiol. 56, 1919-1925.

Bauer-Nebelsick, M., Bardele, C.F., Ott, J.A., 1996a. Electron microscopic studies on Zoothamnium niveum (Hemprich \& Ehrenberg, 1831) Ehrenberg 1838 (Oligohymenophora, Peritrichida), a ciliate with ectosymbiotic, chemoautotrophic bacteria. Eur. J. Protistol. 32, 202-215.
Bauer-Nebelsick, M., Bardele, C.F., Ott, J.a., 1996b. Redescription of Zoothamnium niveum (Hemprich \& Ehrenberg, 1831) Ehrenberg, 1838 (Oligohymenophora, Peritrichida), a ciliate with ectosymbiotic, chemoautotrophic bacteria. Eur. J. Protistol. $32,18-30$.

Bienhold, C., Pop Ristova, P., Wenzhöfer, F., Dittmar, T., Boetius, A., 2013. How deep-sea wood falls sustain chemosynthetic life. PLoS One 8, 10-15.

Cavanaugh, C.M., McKiness, Z.P., Newton, I.L.G., Stewart, F.J., 2013. Marine chemosynthetic symbioses. In: Rosenberg, E., DeLong, E.F., Lory, S., Stackebrandt, E., Thompson, F. (Eds.), The Prokaryotes: Prokaryotic Biology and Symbiotic Associations. Springer, Berlin, Heidelberg, pp. 579-607.

Cole, J.R., Chai, B., Farris, R.J., Wang, Q., Kulam, S.A., McGarrell, D.M., Garrity, G.M., Tiedje, J.M., 2005. The ribosomal database project (RDP-II): sequences and tools for high-throughput rRNA analysis. Nucleic Acids Res. 33, 294-296.

Dubilier, N., Bergin, C., Lott, C., 2008. Symbiotic diversity in marine animals: the art of harnessing chemosynthesis. Nat. Rev. Microbiol. 6, 725-740.

Duperron, S., Lorion, J., Samadi, S., Gros, O., Gaill, F., 2009. Symbioses between deep-sea mussels (Mytilidae: Bathymodiolinae) and chemosynthetic bacteria: diversity, function and evolution. C. R. Biol. 332, 298-310.

Dziallas, C., Allgaier, M., Monaghan, M.T., Grossart, H.P., 2012. Act together-implications of symbioses in aquatic ciliates. Front. Microbiol. 3, 1-17.

Esteban, G.F., Fenchel, T., Finlay, B.J., 2010. Mixotrophy in ciliates. Protist 161, 621-641.

Fagervold, S.K., Galand, P.E., Zbinden, M., Gaill, F., Lebaron, P., Palacios, C., 2012. Sunken woods on the ocean floor provide diverse specialized habitats for microorganisms. FEMS Microbiol. Ecol. 82, 616-628.

Fenchel, T., 1994. Motility and chemosensory behaviour of the sulphur bacterium Thiovulum majus. Microbiology 140, 3109-3116.

Fenchel, T., Finlay, B.J., 1989. Kentrophoros: a mouthless ciliate with a symbiotic kitchen garden. Ophelia 30, 75-93.

Foissner, W., 1979. Peritriche Ciliaten (Protozoa: Ciliophora) aus alpinen Kleingewässern. Zool. Jahrb. Syst. 106, 529-558.

Foissner, W., 2014. An update of basic light and scanning electron microscopic methods for taxonomic studies of ciliated protozoa. Int. J. Syst. Evol. Microbiol. 64, 271-292.

Foissner, W., Schiffmann, H., 1974. Vergleichende Studien an argyrophilen strukturen von vierzehn peritrichen Ciliaten. Protistologica 10, 489-508.

Foissner, W., Berger, H., Kohmann, F., 1992. Taxonomische und Ökologische revision der Ciliaten des Saprobiensystems-Band II: Peritrichida, Heterotrichida Odontostomtida. Informations berichte des Bayer, 5/92. Landesamtes Wasserwirtsch, pp. $1-502$.

Foissner, W., Blake, N., Wolf, K., Breiner, H.W., Stoeck, T., 2009. Morphological and molecular characterization of some peritrichs (Ciliophora: Peritrichida) from tank bromeliads, including two new genera: Orborhabdostyla and vorticellides. Acta Protozool. 48, 291-319.

Fors, Y., Nilsson, T., Risberg, E.D., Sandström, M., Torssander, P., 2008. Sulfur accumulation in pinewood (Pinus sylvestris) induced by bacteria in a simulated seabed environment: impli- 
cations for marine archaeological wood and fossil fuels. Int. Biodeterior. Biodegrad. 62, 336-347.

Frenkiel, L., Gros, O., Mouëza, M., 1996. Gill structure in Lucina pectinata (Bivalvia: Lucinidae) with reference to hemoglobin in bivalves with symbiotic sulphur-oxidizing bacteria. Mar. Biol. 125, 511-524.

Fuchs, B.M., Wallner, G.N., Beisker, W., Schwippl, I., Ludwig, W., Amann, R., 1998. Flow cytometric analysis of the in situ accessibility of Escherichia coli 16S rRNA for fluorescently labeled oligonucleotide probes. Appl. Environ. Microbiol. 64, 4973-4982.

Gast, R.J., Sanders, R.W., Caron, D.A., 2009. Ecological strategies of protists and their symbiotic relationships with prokaryotic microbes. Trends Microbiol. 17, 563-569.

Giribet, G., Carranza, S., Baguñà, J., Riutort, M., Ribera, C., 1996. First molecular evidence for the existence of a Tardigrada + Arthropoda clade. Mol. Biol. Evol. 13, 76-84.

Gros, O., Elisabeth, N.H., Gustave, S.D.D., Caro, A., Dubilier, N., 2012. Plasticity of symbiont acquisition throughout the life cycle of the shallow-water tropical lucinid Codakia orbiculata (Mollusca: Bivalvia). Environ. Microbiol. 14, 1584-1595.

Herry, A., Diouris, M., Le Pennec, M., 1989. Chemoautotrophic symbionts and translocation of fixed carbon from bacteria to host tissues in the littoral bivalve, Loripes lucinalis (Lucinidae). Mar. Biol. 101, 305-312.

Himmel, D., Maurin, L.C., Gros, O., Mansot, J.-L., 2009. Raman microspectrometry sulfur detection and characterization in the marine ectosymbiotic nematode Eubostrichus dianae (Desmodoridae, Stilbonematidae). Biol. Cell 101, 43-54.

Jean, M.R.N., Gonzalez-Rizzo, S., Gauffre-Autelin, P., Lengger, S.K., Schouten, S., Gros, O., 2015. Two new Beggiatoa species inhabiting marine mangrove sediments in the Caribbean. PLoS One 10, e0117832.

Ji, D., Song, W., Al-Rasheid, K.A.S., 2003. Description of a marine peritrichous ciliate, Pseudovorticella sinensis n. sp. (Ciliophora, Peritrichia) from China. J. Eukaryot. Micro Biol. 50, 360-365.

Ji, D., Song, W., Clamp, J., 2006. Pseudovorticella zhengae n. sp., $P$. difficilis (Kahl, 1933) Jankowski, 1976, and P. punctata (Dons, 1918) Warren, 1987, three marine peritrichous ciliates from north China. Eur. J. Protistol. 42, 269-279.

Jorgensen, B.B., Revsbech, N.P., Muyzer, G., Dynamics, E., Nelson, D.C., Revsbech, N.P., Jørgensen, B.B., Russ, L., Speth, D.R., Jetten, M.S.M., Op den Camp, H.J.M., Kartal, B., Shao, M.F., Zhang, T., Fang, H.H.P., Thar, R., Kühl, M., 2013. Microoxicanoxic niche of Beggiatoa spp.: microelectrode survey of marine and freshwater strains. Appl. Environ. Microbiol. 52, 161-168.

Kumar, S., Stecher, G., Tamura, K., 2016. MEGA7: molecular evolutionary genetics analysis version 7.0 for bigger datasets. Mol. Biol. Evol. 33, 1870-1874.

Kusch, J., Czubatinski, L., Wegmann, S., Hubner, M., Alter, M., Albrecht, P., 2002. Competitive advantages of Caedibacterinfected Paramecia. Protist 153, 47-58.

Lane, D.J., 1991. 16S/23S rRNA sequencing. In: Stackebrandt, E., Goodfellow, M. (Eds.), Nucleic Acid Techniques in Bacterial Systematic. John Wiley and Sons, New York, pp. 115-175.

Lane, J., Pace, B., Olsen, G.J., Stahl, D.A., Sogin, M.L., Pace, N.R., Lane, D.J., Pace, B., Olsen, G.J., Stahlt, D.A., Sogint, M.L., Pace, N.R., 1986. Rapid determination of 16S ribosomal RNA sequences for phylogenetic analyses. Proc. Natl. Acad. Sci. 82, $6955-6959$
Laurent, M.C.Z., Gros, O., Brulport, J.P., Gaill, F., Bris, N.L., 2009. Sunken wood habitat for thiotrophic symbiosis in mangrove swamps. Mar. Environ. Res. 67, 83-88.

Laurent, M.C.Z., Le Bris, N., Gaill, F., Gros, O., 2013. Dynamics of wood fall colonization in relation to sulfide concentration in a mangrove swamp. Mar. Environ. Res. 87-88, 85-96.

Leitner, A.R., Foissner, W., 1997. Taxonomic characterization of Epicarchesium granulatum (Kellicott 1887) Jankowki, 1985 and Pseudovorticella elongata (Fromentel, 1876) nov. comb., two peritrichs (Protozoa, Ciliophora) from activated sludge. Eur. J. Protistol. 33, 13-29.

Li, L., Song, W., Warren, A., Shin, M.K., Chen, Z., Ji, D., Sun, P., 2008. Reconsideration of the phylogenetic positions of five peritrich genera, Vorticella, Pseudovorticella, Zoothamnopsis, Zoothamnium, and Epicarchesium (Ciliophora, Peritrichia, Sessilida), based on small subunit rRNA gene sequences. J. Eukaryot. Microbiol. 55, 448-456.

Lynn, D.H., 2008. The Ciliated Protozoa. Characterization, Classification and Guide to the Literature, 3rd ed. Springer, Dordrecht.

Maurin, L.C., Himmel, D., Mansot, J.-L., Gros, O., 2010. Raman microspectrometry as a powerful tool for a quick screening of thiotrophy: an application on mangrove swamp meiofauna of Guadeloupe (F.W.I.). Mar. Environ. Res. 69, 382-389.

Montagna, P.A., Spies, R.B., 1985. Meiofauna and chlorophyll associated with Beggiatoa mats of a natural submarine petroleum seep. Mar. Environ. Res. 16, 231-242.

Moya, A., Peretó, J., Gil, R., Latorre, A., 2008. Learning how to live together: genomic insights into prokaryote-animal symbioses. Nat. Rev. Genet. 9, 218-229.

Ott, J., Bright, M., Bulgheresi, S., 2004. Marine microbial thiotrophic ectosymbioses. Oceanogr. Mar. Biol. Annu. Rev. 42, 95-118

Palacios, C., Zbinden, M., Pailleret, M., Gaill, F., Lebaron, P., 2009. Highly similar Prokaryotic communities of sunken wood at shallow and deep-sea sites across the oceans. Microb. Ecol. 58, 737-752.

Pascal, P.Y., Dubois, S., Boschker, H.T.S., Gros, O., 2014. Trophic role of large benthic sulfur bacteria in mangrove sediment. Mar. Ecol. Prog. Ser. 516, 127-138.

Powell, E.N., Bright, T.J., Woods, A., Gittings, S., 1983. Meiofauna and the thiobios in the east flower garden brine seep. Mar. Biol. 73, 269-283.

Rinke, C., 2002. Carbon Fixation, Incorporation and Transfer in the Chemoautotrophic Zoothamnium Niveum Symbioses with 14C Bicarbonate Autoradiography. Diploma Thesis. University of Vienna.

Rinke, C., Lee, R., Katz, S., Bright, M., 2007. The effects of sulphide on growth and behaviour of the thiotrophic Zoothamnium niveum symbiosis. Proc. Biol. Sci. 274, 2259-2269.

Rosati, G., 2004. Ectosymbiosis in ciliated protozoa. Symbiosis Mech. Model Syst., 477-488.

Rosati, G., Petroni, G., Quochi, S., Modeo, L., Verni, F., 1999. Epixenosomes: Peculiar epibionts of the hypotrich ciliate Euplotidium itoi defend their host against predators. J. Eukaryot. Microbiol. 46, 278-282.

Rozen, S., Skaletsky, H., 2000. Primer3 on the WWW for general users and for biologist programmers. In: Krawetz, S., Misener, S. (Eds.), Bioinformatics Methods and Protocols. Humana Press, Totowa, NJ, pp. 365-386.

Sauvadet, A., 2015. Interactions entre ciliés et métazoaires dans deux environnements marins contrastés: les sources hydrother- 
males et les sédiments anoxiques. Thèse de Doctorat de 1’Université Pierre et Marie Curie, spécialité Biologie marine. Ecole Doctorale Diversité du Vivant, 197 p.

Schuster, L., Bright, M., 2016. A novel colonial ciliate Zoothamnium ignavum sp. nov. (Ciliophora, Oligohymenophorea) and its ectosymbiont Candidatus Navis piranensis gen. nov., sp. nov. from shallow-water wood falls. PLoS One 11, 1-24.

Song, W., Warren, A., 2000. A redescription of Pseudovorticella patellina (O F. Müller, 1776) nov. comb., a peritrichous ciliate (Protozoa: Ciliophora: Peritrichida) isolated from mariculture biotopes in north China. Acta Protozool. 39, 43-50.

Stocker, R., Seymour, J.R., 2012. Ecology and physics of bacterial chemotaxis in the ocean. Microbiol. Mol. Biol. Rev. 76, 792-812.

Sun, P., Al-Farraj, S.A., Warren, A., Ma, H., 2017. Morphology of four new solitary sessile peritrich ciliates from the Yellow Sea, China, with description of an unidentified species of Paravorticella (Ciliophora, Peritrichia). Eur. J. Protistol. 57, 73-84.

Sun, P., Ma, H., Shin, M.K., Al-Rasheid, K.A.S., 2013. Morphology of two new marine peritrich ciliates from Yellow Sea, Pseudovorticella dingi nov. spec. and $P$. wangi nov. spec., with supplementary descriptions of $P$. plicata, $P$. banatica and $P$. anomala (Ciliophora, Peritrichia). Eur. J. Protistol. 49, 467-476.

Sun, P., Song, W., Warren, A., 2006. Taxonomic characterization of two marine peritrichous ciliates, Epicarchesium corlissi n. sp. and Pseudovorticella jiangi n. sp. (Ciliophora: Peritrichia), from northern China. Eur. J. Protistol. 42, 281-289.
Taylor, G.T., Sullivan, C.W., 1984. The use of 14C-labeled bacteria as a tracer of ingestion and metabolism of bacterial biomass by microbial grazers. J. Microbiol. Methods 3, 101-124.

Vopel, K., Pöhn, M., Sorgo, A., Otto, J., 2001. Ciliategenerated advective seawater transport supplies chemoautotrophic ectosymbionts. Mar. Ecol. Prog. Ser. 210, 93-99.

Vopel, K., Reick, C.H., Arlt, G., Pöhn, M., Ott, J.a., 2002. Flow microenvironment of two marine peritrich ciliates with ectobiotic chemoautotrophic bacteria. Aquat. Microb. Ecol. 29, 19-28.

Wallner, G., Amann, R., Beisker, W., 1993. Optimizing fluorescent in situ hybridization with rRNA targeted oligonucleotide probes for flow cytometric identification of microorganisms. Cytometry 14, 136-143.

Warren, A., 1986. A revision of the genus Vorticella (Ciliophora: Peritrichida). Bull. Br. Mus. Nat. Hist. (Zool.) 50, 1-57.

Warren, A., 1987. A revision of the genus Pseudovorticella Foissner \& Schiffmann, 1974 (Ciliophora: Peritrichida). Bull. Br. Mus. Nat. Hist. (Zool.) 52, 1-12. 